\title{
The Relationship among Self-Efficacy Beliefs, External Locus of Control and Work Stress in Public Setting Schoolteachers
}

\author{
Maura I. Cascio, Paola Magnano, Silvia Elastico, Valentina Costantino, \\ Valentina Zapparrata, Antonino Battiato \\ Faculty of Human and Social Sciences, University of Enna "KORE", Enna, Italy \\ Email: maura.cascio@unikore.it, paola.magnano@unikore.it, silvia.elastico@unikore.it
}

Received 3 October 2014; revised 6 November 2014; accepted 13 November 2014

Copyright (C) 2014 by authors and Scientific Research Publishing Inc.

This work is licensed under the Creative Commons Attribution International License (CC BY). http://creativecommons.org/licenses/by/4.0/

\section{(c) (i) Open Access}

\begin{abstract}
Work stress is considered as the product of an imbalance between environmental demands (stressors) and individual differences (capabilities, resources or needs), associated with adverse health outcomes as well as adverse work outcomes. According to the literature in this field, teaching has ranked among the most stressful occupation. In order to investigate the role of Self-Efficacy Beliefs and Locus of Control as personal capabilities to cope with environmental demands, this study examines the interactions among these psychological features in a group of schoolteachers. Results of this survey suggest that self-efficacy belief represents one of the most important "protective" factors in response to psychological stress.
\end{abstract}

\section{Keywords}

Work Stress Models, Personality and Individual Differences, Self Efficacy, Locus of Control, Risk Assessment

\section{Introduction}

Stress at work can happen in any sector and in any size of organization, affecting the health of individuals and the health of organizations (European Agency for Safety and Health at Work, 2003). Teaching has been identified as one of the most stressful professions that can lead to serious deterioration of physical and psychological health [1]-[7]. Many international studies have shown that up to one third of teachers are stressed or extremely stressed [8]-[15]. Teachers' work stress reflects the experience of unpleasant emotions as a result of teaching work [11], and it is associated with several negative outcomes for teachers, including increased burnout and ab- 
senteeism [16], reduced sense of teaching efficacy, lower levels of job satisfaction and commitment [17].

Self-efficacy is the key construct in Bandura's Social Cognitive Theory [18], and represents people's beliefs about their capabilities to produce designated levels of performance that exercise influence over events that affect their lives [19]. Self-efficacy theory extends the conception of agent causality to people's beliefs in their collective efficacy to produce desired outcomes [20]. Therefore, perceived individual self-efficacy has used to understand individual behavior as a function of domain-specific beliefs about personal capacities, while perceived collective self-efficacy is the extension of the self-efficacy construct to organizations and groups; it refers to beliefs about collective capacities in specific domains. Efficacy's beliefs have a powerful influence on behavior [21] [22], job involvement and job satisfaction [23] and play an important role in health outcomes [24]-[28]. In terms of feeling, a low sense of self-efficacy is associated with depression, anxiety, and helplessness [25]. Self-efficacy in teaching refers to teachers' beliefs about their own values, competencies, and accomplishment [29]. The sources of teachers' self-efficacy come from the way they master their direct experience, their level of anxiety in facing or interpreting their tasks, their imitations of other teacher models, and the social persuasion or specific feedback form significant others [30]. Self-efficacy in teaching has been linked with important outcomes for teachers, including the use of effective teaching strategies [31]-[33], better classroom management [34], and greater teacher well-being [35]-[37]. In addition, Klassen and Chiu [38] found that teachers' experience of stress was an important contributor to their sense of teaching efficacy.

Defined as a generalized expectancy for internal as opposed to external control of reinforcements [39] [40], LOC is another important component of individual wellness. This construct has a significant impact on Bandura's self-efficacy theories [21] and how individuals' expectations shape the goals, they set for themselves. Individuals with internal LOC engage more than do individuals with external LOC, because they believe that their achievement depends on their will [39]-[41]. They feel to have choice in their lives and control over their circumstances [39] [42] [43], and they tend to feel happier, free, and less stressed [27]. At the other end of the continuum, individuals with a more external LOC perceive themselves to have little or no control over their lives; they tend to feel more susceptible to stress and depression too. This one-dimensional construct (internal versus external control) is been questioned repeatedly, giving rise to more elaborate conceptualizations [40] [44] [43]: however, adults generally do not present a solely internal or external LOC searching for an optimal fit in their system of beliefs.

According to Lazarus and Folkman [45], who considered Self-Efficacy Beliefs and Locus of Control (hereafter named "LOC") as appraisal variables within stress and coping theory, this study aims to investigate the effects of perceived self-efficacy [24] [26]-[28] and LOC [39] [40] [46]-[49] in the relationship with work related stress in schoolteachers.

\section{Methodology}

\subsection{Instruments}

Work related stress was investigated through the Italian version of Occupational Stress Indicator (OSI) [48], [50], a self-report questionnaire composed of 167 items rated on a 6-point Likert scale and developed on the basis of the Cooper's model. Cronbach's $\alpha$ for the subscale coefficients is ranged from 0.72 to 0.86 [50]. The test is composed by six scales based on 4 factors: stressors, individual's features, coping strategies and stress symptoms. Stress can be either psychological or physical: both forms of stress are similar and the majority of people suffer from a combination of these two types of stress. OSI's "PSYT" scale denotes psychological stress and taps a range of cognitive aspects of strain. It consists of 18 items; Cronbach's $\alpha$ value calculated on our sample is 0.81 . OSI "PHIT" scores look at the somatic symptoms of anxiety and depression: this scale consists of 12 items; Cronbach's $\alpha$ value calculated on our sample is 0.75 . In addition, we analyzed the OSI "Locus of control" scale's results that consists of three subscale (12 items). The items of "organizational forces" measure the extent to which the respondents perceive their effect over the invisible influences within the organization; "Management processes" investigate how subjects perceive their control over performances appraisal and promotions; "Individual influence" examines a more general ability to have effects within the workplace. We calculated $\alpha$ value on our sample, which is respectively 0.77 (LOC-O), 0.79 (LOC-G), and 0.82 (LOC-I). The three subscale are been summated to obtain an overall perceived LOC.

Perceived self-efficacy was measured through the following Italian versions of Bandura's Tests [21]:

1) EPOP (Perceived Personal Self-Efficacy in Organizations), a self-report questionnaire composed by 6 
items rated on a 7-point Likert scale, covering the degree of belief that one is capable of performing in a certain manner to achieve certain goals (Cronbach's $\alpha=0.79$ );

2) ECOP (Perceived Collective Self-Efficacy in Organizations), a self-report questionnaire composed by 6 items rated on a 7-point Likert scale covering group-level property (Cronbach's $\alpha=0.88$ ). Collective self-efficacy is the extension of the self-efficacy construct to organizations and groups: indeed, people's shared beliefs in their collective power to produce desired results is a key ingredient of collective agency [26].

\subsection{Participants}

The participants were 222 teachers $(M=85 ; F=130$; missing gender $=7$ ), aged 25 - 55 years, recruited from twelve public schools in Italy. Table 1 shows gender distribution between age levels.

\subsection{Procedure}

A two-step analysis has been conducted before studying the possible effects of these psychological features on distress. An explorative analysis, based on parametric tests, allowed knowing if the subjects' responses varied according to gender and age (see Table 2 and Table 3). At this stage, T-test has carried out. Then, in order to investigate the structure of the relationship among the instrumental variables, Pearson's correlations have applied (see Table 4). Finally, for modeling the relationship between the investigated features (Perceived Personal Self-Efficacy, Perceived Collective Self-Efficacy, Total LOC) and, respectively, physical illness and psychological stress (dependent variables), we have used linear regression (see Table 5 and Table 6).

Table 1. Gender and age level distribution.

\begin{tabular}{ccccc}
\hline & Males & Females & Missing & Total \\
\hline 25 - 50 years & 49 & 87 & 7 & 143 \\
Over 50 years & 35 & 43 & 0 & 78 \\
Missing & 1 & 0 & 0 & 1 \\
Total & 85 & 130 & 7 & 222 \\
\hline
\end{tabular}

Table 2. Gender differences, Student's t test.

\begin{tabular}{|c|c|c|c|c|c|}
\hline & Mal & $\mathrm{N}=85$ & Females & $\mathrm{N}=130$ & \multirow{2}{*}{ p-value } \\
\hline & M & SD & M & SD & \\
\hline Physical illness & 32.47 & 13.90 & 31.18 & 11.92 & 0.47 \\
\hline Psychological stress & 58.05 & 14.16 & 55.73 & 12.45 & 0.21 \\
\hline Perceived Personal Self-Efficacy & 31.11 & 8.54 & 33.45 & 5.74 & 0.02 \\
\hline Perceived Collective Self-Efficacy & 28.71 & 8.26 & 30.81 & 6.97 & 0.04 \\
\hline Total LOC & 42.08 & 6.70 & 39.95 & 6.65 & 0.02 \\
\hline
\end{tabular}

Table 3. Age-level differences, Student's t test.

\begin{tabular}{|c|c|c|c|c|c|}
\hline & \multicolumn{2}{|c|}{ Under 50 years old $N=143$} & \multicolumn{2}{|c|}{ Over 50 years old $N=78$} & \multirow{2}{*}{ p-value } \\
\hline & M & SD & M & SD & \\
\hline Physical illness & 53.35 & 13.74 & 61.15 & 11.22 & 0.00 \\
\hline Psychological stress & 29.32 & 13.03 & 34.28 & 12.42 & 0.00 \\
\hline Perceived Personal Self-Efficacy & 33.93 & 5.59 & 30.45 & 8.74 & 0.03 \\
\hline Perceived Collective Self-Efficacy & 30.99 & 7.10 & 20.78 & 8.27 & 0.00 \\
\hline Total LOC & 38.99 & 7.53 & 43.23 & 5.75 & 0,00 \\
\hline
\end{tabular}


Table 4. Pearson's correlations.

\begin{tabular}{cccccc}
\hline & Physical illness & $\begin{array}{c}\text { Psychological } \\
\text { stress }\end{array}$ & $\begin{array}{c}\text { Perceived Personal } \\
\text { Self-Efficacy }\end{array}$ & $\begin{array}{c}\text { Perceived Collective } \\
\text { Self-Efficacy }\end{array}$ & Total LOC \\
Physical illness & - & $0.53^{* *}$ & $-0.39^{* *}$ & $-0.49^{* *}$ & $0.42^{* *}$ \\
Psychological stress & $0.53^{* *}$ & - & $-0.53^{* *}$ & $-0.35^{* *}$ & $0.66^{* *}$ \\
$\begin{array}{c}\text { Perceived Personal } \\
\text { Self-Efficacy }\end{array}$ & $-0.39^{* *}$ & $-0.53^{* *}$ & - & $0.61^{* *}$ & $-0.44^{* *}$ \\
$\begin{array}{c}\text { Perceived Collective } \\
\text { Self-Efficacy }\end{array}$ & $-0.34^{* *}$ & $-0.49^{* *}$ & $0.61^{* *}$ & $-0.42^{*}$ \\
Total external LOC & $0.40^{* *}$ & $0.66^{* *}$ & $-0.44^{* *}$ & $-0.42^{*}$ & - \\
${ }^{*} \mathrm{p}<0.05 ;{ }^{* *} \mathrm{p}<0.01$. & & & & &
\end{tabular}

Table 5. Linear regressions between physical illness, self-efficacy and LOC. Beta coefficient for each regression $\left({ }^{*} \mathrm{p}(\mathrm{t})<0.01\right)$.

\begin{tabular}{cc}
\hline Independent variables & Dependent variable physical illness \\
\hline Perceived Personal Self-Efficacy & $-0.21^{*}$ \\
Perceived Collective Self-Efficacy & 0.09 \\
Total LOC & $0.28^{*}$ \\
\hline
\end{tabular}

Table 6. Linear regressions between psychological stress, self-efficacy and LOC. Beta coefficient for each regression $\left({ }^{*} \mathrm{p}(\mathrm{t})<0.05\right)$.

\begin{tabular}{cc}
\hline Independent variables & Dependent variable psychological stress \\
\hline Perceived Personal Self-Efficacy & $-0.22^{*}$ \\
Perceived Collective Self-Efficacy & $-0.14^{*}$ \\
Total LOC & $0.51^{*}$ \\
\hline
\end{tabular}

The participants have been informed about the purpose of the study and they gave their informed consent. Teachers have been tested individually in a quiet room that is been arranged for the experimental procedure. The experimental procedure is been explained to the teachers, and they participated to the study filling out the questionnaires in a group setting, anonymously, voluntarily, without time restrictions. This procedure has reviewed and approved by the Ethics Commission of Kore University.

\section{Results}

Table 2 shows gender differences in perceived physical and psychological stress self-efficacy and external LOC. According to the literature in this field [17] [51] [52], results demonstrate that females perceive more positive outcomes of their activity (as Perceived Self-Efficacy and Collective Efficacy scores demonstrate) and, consequently, they perceive less stress than men. These results are statistically significant (Table 2): this output could be explained by women's ability to express emotions and manage stress interacting with social supports (friends, partner, or others) more than men do.

Indeed, result shows that males experience more stress than females and, consequently, less control. This output is significant.

Table 3 shows age-level differences in perceived stress—physical and psychological—self-efficacy and external LOC. In particular:

1) Teachers over 50 years old experience more stress than the other group and, consequently, less control;

2) Teachers under 50 years old experience more Perceived Personal and Collective Self-Efficacy than the other group. Indeed, they seem to be able to cope with stress better than the other group.

According to the literature in this field [53] [54], all these results are statistically significant and demonstrate 
that age is one of the most important risk factor for stress.

The correlation coefficients shown in Table 4 indicate statistically significant bivariate correlations between the variables. Perceived Self-Efficacy and total external LOC seem to be inversely related, like the relationship between physical illness and psychological stress and efficacy, while the relation between physical illness and psychological stress seems to be positively related to external LOC. All these results are statistically significant (Table 4).

Finally, we have applied linear regression. The results suggest an overall effect of Perceived Personal Self-Efficacy, Collective Self-Efficacy and external LOC on stress as follows:

1) Lower levels of Personal Self-Efficacy and higher levels of external LOC can be considered predictors of physical illness (Table 5);

2) Psychological stress is negatively predicted by self-efficacy and positively predicted by external LOC (Table 6).

According to Lazarus and Folkman [45], these results demonstrate a significant relation between Self-Efficacy and LOC on distress: self-efficacy seems to be an important "protective" factor, while external LOC seems to be a "critical" risk factor.

\section{Discussion}

Work stress has considered as the product of an imbalance between environmental demands (stressors) and individual differences [45] [55]-[58]: Self-Efficacy and Locus of Control, as personal capabilities to cope with environmental demands, represent some of the most important resource factors in stress appraisal processes [45]. According to the literature in this field, the results of this survey demonstrate that teacher' self-efficacy is a personal resource factor that may protect from the experience of job strain [28]. In terms of feeling, people with a strong sense of self-efficacy view challenging problems and recover quickly from setbacks and disappointments. Because of these appraisals, the impact of the stressful events has reduced and has less negative impact on the health of the individual [59].

Additionally, the results demonstrate that individuals with external locus of control tend to be more stressed. As Rotter [39] [46], and Lazarus [45] demonstrated, having control in a stressful encounter is stress reducing and not having control is stress inducing. Therefore, people with an internal LOC manage stress better [60]. In particular, this study has pointed out the effect of age on the distress experienced by schoolteachers: results demonstrate that teachers over 50 years old experience more stress than the other group. They have less Perceived Personal and Collective Self-Efficacy and, consequently, they seem to be able to cope with stress worst than teachers under 50 years old. It could be explained by the general increase of existential sources of stress, for example, or of the chronic problems of infirmity, limited energy, loneliness, and a hostile or unresponsive environment [61].

\section{Conclusions}

Work-related stress can affect anyone in any sector and in any size of organisation, compromising the health of individuals and the health of organizations. Indeed, problems at work are more strongly associated with adverse health outcomes as well as adverse work outcomes.

Many studies have shown that teaching has ranked among the most stressful occupation [1] [4] [6] [7] [10], [11] [13]: for teachers high levels of work stress seem to reduce effectiveness and commitment to the profession, to increase absenteeism and to lead to serious deterioration of physical and psychological health.

According to the literature in this field, the main findings of this study seem to suggest that stress can be considered as a person-bound variable [62], and personality depends on the individual perception of one's own reality. Moreover, this perception determines how an individual will respond [47]. However, social influence is not unconfined with perceived self-efficacy. Peer pressure usually appears to have higher predictive value, and its counterpart, social support has a high potential as a resource factor [63]. The degree to which peer pressure makes a difference also depends on the individual's resistance self-efficacy; the degree to which social support operates also rests on one's self-efficacy to build, maintain and mobilize social networks [25].

With these regards, enhancing general self-efficacy by coping skills training is an important question for research in school-teachers as other helping professionals [1] [22] [24] [26] [28] [64], because it allows appraising a situation positively and reducing both physiological and emotional reactivity [53], which enhances with age. 


\section{References}

[1] Travers, C. and Cooper, L. (1998) Increasing Costs of Occupational Stress for Teachers. In: Dunham, J. and Varma, V., Eds., Stress in Teachers: Past, Present, and Future, Whurr, London, 57-75.

[2] Chan, D.W. and Hui, E.K.P. (1995) Burnout and Coping among Chinese Secondary School Teachers in Hong Kong. British Journal of Educational Psychology, 65, 15-25. http://dx.doi.org/10.1111/j.2044-8279.1995.tb01128.x

[3] Zurlo, M.C., Pes, D. and Cooper, C. L. (2007) Stress in Teaching: A Study of Occupational Stress and Its Determinants among Italian Schoolteachers. Stress and Health, 23, 231-241. http://dx.doi.org/10.1002/smi.1141

[4] Guglielmi, R. S. and Tatrow, K. (1998) Occupational Stress, Burnout, and Health in Teachers: A Methodological and Theoretical Analysis. Review of Educational Research, 68, 61-99. http://dx.doi.org/10.3102/00346543068001061

[5] Maslach, C. and Leiter, M.P. (1997) The Truth about Burnout: How Organizations Cause Personal Stress and What to Do about It. Jossey-Bass, San Francisco.

[6] Di Nuovo, S. and Commodori, E. (2004) Costi psicologici del curare. Stress e Burnout nelle professioni di aiuto. Bonanno Editore, Roma.

[7] Avallone, F. and Paplomatas, A. (2005) Salute organizzativa. Psicologia del benessere nei contesti lavorativi. Raffaello Cortina Editore, Milano.

[8] Kyriacou, C. and Sutcliffe, J. (1979) A Note on Teacher Stress and Locus of Control. Journal of Occupational Psychology, 52, 227-228. http://dx.doi.org/10.1111/j.2044-8325.1979.tb00456.x

[9] Borg, M. G. and Riding, R. J. (1991) Occupational Stress and Satisfaction in Teaching. British Educational Research Journal, 17, 263-281. http://dx.doi.org/10.1080/0141192910170306

[10] Kyriacou, C. (2000) Stress-Busting for Teachers. Nelson Thornes, Cheltenham.

[11] Kyriacou, C. (2001) Teacher Stress: Directions for Future Research. Educational Review, 53, 27-35. http://dx.doi.org/10.1080/00131910120033628

[12] Thomas, N., Clarke, V. and Lavery, J. (2003) Self-Reported Work and Family Stress of Female Primary Teachers. Australian Journal of Education, 47, 73-87. http://dx.doi.org/10.1177/000494410304700106

[13] De Nobile, J.J. and McCormick, J. (2005) Job Satisfaction and Occupational Stress in Catholic Primary Schools. Leading \& Managing, 13, 31-48.

[14] Geving, A.M. (2007) Identifying the Types of Student and Teacher Behaviours Associated with Teacher Stress. Teaching and Teacher Education, 23, 624-640. http://dx.doi.org/10.1016/j.tate.2007.02.006

[15] Al-Fudail, M. and Mellar, H. (2008) Investigating Teacher Stress When Using Technology. Computers and Education, 51, 1103-1110. http://dx.doi.org/10.1016/j.compedu.2007.11.004

[16] McCarthy, C.J., Lambert, R.G., O’Donnell, M. and Melendres, L.T. (2009) The Relation of Elementary Teachers’ Experience, Stress, and Coping Resources to Burnout Symptoms. The Elementary School Journal, 109, 282-300. http://dx.doi.org/10.1086/592308

[17] Klassen, R.M. and Chiu, M.M. (2011) The Occupational Commitment and Intention to Quit of Practicing and PreService Teachers: Influence of Self-Efficacy, Job Stress, and Teaching Context. Contemporary Educational Psychology, 36, 114-129. http://dx.doi.org/10.1016/j.cedpsych.2011.01.002

[18] Bandura, A. (1977) Self-Efficacy: Toward a Unifying Theory of Behavioral Change. Psychological Review, 84, 191215. http://dx.doi.org/10.1037/0033-295X.84.2.191

[19] Bandura, A. (1994) Self-Efficacy. In: Ramachaudran, V.S., Ed., Encyclopedia of Human Behavior, Vol. 4, Academic Press, New York, 71-81.

[20] Bandura, A. (1998) Personal and Collective Efficacy in Human Adaptation and Change. In: Adair, J.G., Belanger, D. and Dion, K.L., Eds., Advances in Psychological Science: Vol. 1. Personal, Social and Cultural Aspects, Psychology Press, Hove, 51-71.

[21] Bandura, A. (1986) Social Foundations of Thought and Action. Prentice Hall, Englewood Cliffs.

[22] Bandura, A. (1989) Self-Efficacy Mechanism in Physiological Activation and Health-Promoting Behavior. In: Madden, J., Matthysse, S. and Barchas, J., Eds., Adaptation, Learning and Affect, Raven, New York, 1169-1188.

[23] Caprara, G.V., Barbaranelli, C., Borgogni, L. and Steca, P. (2003) Efficacy Beliefs as Determinants of Teachers' Job Satisfaction. Journal of Educational Psychology, 95, 821-832. http://dx.doi.org/10.1037/0022-0663.95.4.821

[24] Schwarzer, R. (1993) Measurement of Perceived Self-Efficacy. Psychometric Scales for Cross-Cultural Research. Freie Universität Berlin, Berlin.

[25] Schwarzer, R. and Fuchs, R. (1995) Self-Efficacy and Health Behaviours. In: Conner, M. and Norman, P., Eds., Predicting Health Behaviour: Research and Practice with Social Cognition Models, Open University Press, Buckingham, 
163-196.

[26] Bandura, A. (1997) Self-Efficacy: The Exercise of Control. W.H. Freeman and Company, New York.

[27] Caprara, G.V. (2001) La valutazione dell'autoefficacia. Costrutti e strumenti. Edizioni Erickson, Trento.

[28] Schwarzer, R. and Hallum, S. (2008) Perceived Teacher Self-Efficacy as a Predictor of Job Stress and Burnout: Mediation Analyses. Applied Psychology, 57, 152-171. http://dx.doi.org/10.1111/j.1464-0597.2008.00359.x

[29] Rots, I., Aelterman, A., Vlerick, P. and Vermeulen, K. (2007) Teacher Education, Graduates’ Teaching Commitment and Entrance into the Teaching Profession. Teaching and Teacher Education, 23, 543-556. http://dx.doi.org/10.1016/j.tate.2007.01.012

[30] Cardelle-Elawar, M., Irwin, L. and Sanz de Acedo Lizarraga, M.L. (2007) A Cross Cultural Analysis of Motivational Factors that Influence Teacher Identity. Electronic Journal of Research in Educational Psychology, 5, 565-592.

[31] Guskey, T.R. (1988) Mastery Learning and Mastery Teaching: How They Complement Each Other. Principal, 68, 6-8.

[32] Ross, J.A. (1994) Beliefs that Make a Difference: The Origins and Impacts of Teacher Efficacy. Teaching of Psychology, 26, 264-268.

[33] Woolfolk Hoy, A. and Burke Spero, R. (2005) Changes in Teacher Efficacy during the Early Years of Teaching: A Comparison of Four Measures. Teaching and Teacher Education, 21, 343-356. http://dx.doi.org/10.1016/j.tate.2005.01.007

[34] Tsouloupas, C.N., Carson, R.L., Matthews, R., Grawitch, M.J. and Barber, L.K. (2010) Examining Teachers’ Emotional Regulation Strategies as Mediators between Student Disruptive Behaviour and Teacher Burnout. Educational Psychology, 30, 173-189. http://dx.doi.org/10.1080/01443410903494460

[35] Egyed, C.J. and Short, R.J. (2006) Teacher Self-Efficacy, Burnout, Experience and Decision to Refer a Disruptive Student. School Psychology International, 27, 462-474. http://dx.doi.org/10.1177/0143034306070432

[36] Smylie, M.A. (1988) The Enhancement Function on Staff Development: Organizational and Psychological Antecedents to Individual Teacher Change. American Educational Research Journal, 25, 1-30. http://dx.doi.org/10.3102/00028312025001001

[37] Tschannen-Moran, M. and Woolfolk, H.A. (2001) Teacher Efficacy: Capturing and Elusive Construct. Teaching and Teacher Education, 17, 783-805. http://dx.doi.org/10.1016/S0742-051X(01)00036-1

[38] Klassen, R.M. and Chiu, M.M. (2010) Effects on Teachers' Self-Efficacy and Job Satisfaction: Teacher Gender, Years of Experience, and Job Stress. Journal of Educational Psychology, 102, 741-756. http://dx.doi.org/10.1037/a0019237

[39] Rotter, J.B. (1966) Generalized Expectancies for Internal versus External Control of Reinforcement. Psychological Monographs, 80, 1-28. http://dx.doi.org/10.1037/h0092976

[40] Lefcourt, H.M. (1976) Internal versus External Control of Reinforcement: A Review. Psychological Bulletin, 65, 206220. http://dx.doi.org/10.1037/h0023116

[41] Brown, J.S. and Duguid, P. (2000) Organizational Learning and Community-of-Practice: Toward a Unified View of Working, Learning and Innovation. In: Crorr, R. and Israelit, S., Eds., Strategic Learning in a Knowledge Economy, Butterworth-Heinemann, Woburn, 143-165.

[42] Weiner, B., Frieze, I.H., Kukla, A., Reed, L., Rest, S. and Rosembaum, R.M. (1971) Perceiving the Causes of Success and Failure. General Learning Press, Morristown.

[43] Levenson, H. (1981) Differentiating among Internally, Powerful Others and Change. In: Research with the Locus of Control Construct, Vol. 1, Academic Press, New York, 15-63.

[44] Levenson, H. (1973) Differentiating among Internally, Powerful Others and Internal Locus of Control Orientations. Developmental Psychology, 9, 260-265. http://dx.doi.org/10.1037/h0035127

[45] Lazarus, R.S. and Folkman, S. (1984) Stress, Appraisal, and Coping. Springer, New York.

[46] Rotter, J.B. (1975) Some Problems and Misconceptions Related to the Construct of Internal versus External Control of Reinforcement. Journal of Consulting and Clinical Psychology, 43, 56-67. http://dx.doi.org/10.1037/h0076301

[47] Rotter, J.B. (1986) Il ruolo della situazione psicologica nel determinare la direzione del comportamento umano. In: Caprara, G.V. and Luccio, R. (a cura di), Teorie della personalità II. Gli sviluppi, Il Mulino, Bologna, 27-145.

[48] Cooper, C.L., Sloan, S.J. and Williams, S. (1998) Stress Indicator Management Guide. Nfer Nelson, Windsor. (tr. it. Occupational Stress Indicator: Manuale. Organizzazioni Speciali, Firenze)

[49] Perussia, F. and Viano, R. (2008) Mini Locus of Control Scale. Piccolo manuale, con Tratti e Tipi, da una Scala psicometrica semplificata. In: Di Nuovo, S. and Sprini, G., (a cura di), Teorie e metodi della psicologia italiana. Tendenze attuali, Franco Angeli Editore, Milano, 457-468.

[50] Sirigatti, S. and Stefanile, C. (2002) OSI, Occupational Stress Indicator: Adattamento italiano. Organizzazioni Speciali 
(OS), Firenze.

[51] Archer, J. and Lloyd, B.B. (2002) Sex and Gender. 2nd Edition, Cambridge University Press, Cambridge. http://dx.doi.org/10.1017/CBO9781139051910

[52] Baron-Cohen, S. (2003) The Essential Difference: The Truth about the Male and Female, Basic Books, New York. (tr. it. 2004. Questione di cervello. La differenza essenziale tra uomini e donne, Mondadori, Milano)

[53] Endler, N.S., Speer, R.L., Johnson, J.M. and Flett, G.L. (2001) General Self-Efficacy and Control in Relation to Anxiety and Cognitive Performance. In: Current Psychology: Developmental, Learning, Personality, Social, Vol. 20, Springer-Verlag, Berlin, 36-52. http://dx.doi.org/10.1007/s12144-001-1002-7

[54] Fisher, M.H. (2011) Factors Influencing Stress, Burnout, and Retention of Secondary Teachers. Current Issues in Education, 14, 1-37.

[55] French, J.R. and Kahn, R.L. (1962) A Programmatic Approach to Studying the Industrial Environment and Mental Health. Journal of Social Issues, 18, 1-47. http://dx.doi.org/10.1111/j.1540-4560.1962.tb00415.x

[56] Lazarus, R.S. and Launier, R. (1978) Stress-Related Transactions between Persons and Environment. In: Pervin, L.A. and Lewis, M., Eds., Perspectives in Interactional Psychology, Plenum, New York, 287-327.

[57] Cooper, D. (1988) Occupational Stress Indicator Management Guide. NFER-Nelson, Windor.

[58] Magrin, M.E. (2008) Dalla resistenza alla resilienza: Promuovere benessere nei luoghi di lavoro. Giornale Italiano di Medicina del Lavoro ed Ergonomia, 30, 11-19.

[59] Bandura, A. (1982) Self-Efficacy Mechanism in Human Agency. American Psychologist, 37, 122-147. http://dx.doi.org/10.1037/0003-066X.37.2.122

[60] Krause, N. and Stryker, S. (1984) Stress and Well-Being: The Buffering Role of Locus of Control Beliefs. Social Science \& Medicine, 18, 783-790. http://dx.doi.org/10.1016/0277-9536(84)90105-9

[61] Lazarus, R.S. and DeLongis, A. (1983) Psychological Stress and Coping in Aging. American Psychologist, 38, 245254. http://dx.doi.org/10.1037/0003-066X.38.3.245

[62] Mischel, V. (1986) Verso una riconcettualizzazione della personalità nella teoria dell'apprendimento cognitivo-sociale. In: Caprara, G.V. and Luccio, R., Eds., Teorie della personalità II. Gli sviluppi, Il Mulino, Bologna, 27-145.

[63] Schwarzer, R. and Leppin, A. (1991) Social Support and Health: A Theoretical and Empirical Overview. Journal of Social and Personal Relationships, 8, 99-127. http://dx.doi.org/10.1177/0265407591081005

[64] Smith, R.E. (1989) Effects of Coping Skills Training on Generalized Self-Efficacy and Locus of Control. Journal of Personality and Social Psychology, 56, 228-233. http://dx.doi.org/10.1037/0022-3514.56.2.228 
Scientific Research Publishing (SCIRP) is one of the largest Open Access journal publishers. It is currently publishing more than 200 open access, online, peer-reviewed journals covering a wide range of academic disciplines. SCIRP serves the worldwide academic communities and contributes to the progress and application of science with its publication.

Other selected journals from SCIRP are listed as below. Submit your manuscript to us via either submit@scirp.org or Online Submission Portal.
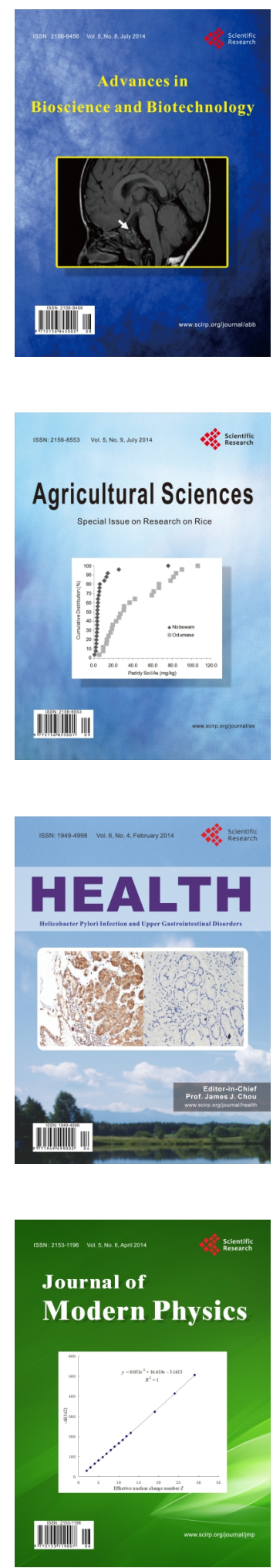
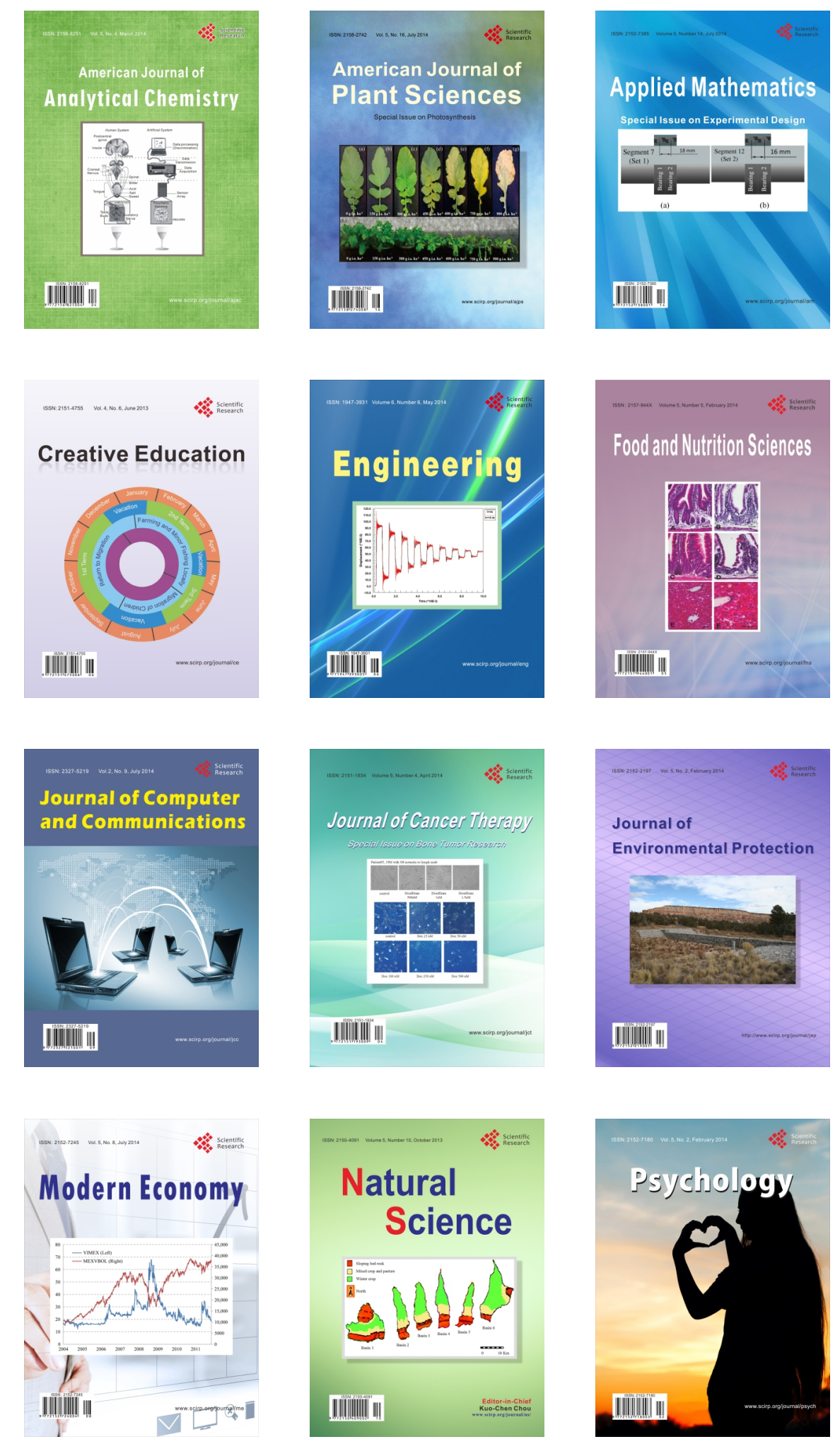